The Voices of Memoria: Diaria, Historiae, and Annuaria as Records of Experience in the Pre-suppression Society

\author{
Author: Paul Shore
}

Source: Engaging Sources: The Tradition and Future of Collecting History in the Society of Jesus (Proceedings of the Symposium held at Boston College, June 11-13, 2019)

Edited by: Cristiano Casalini, Emanuele Colombo, and Seth Meehan

ISBN: 978-1-947617-09-4

Published by: Institute of Jesuit Sources

Originally Published: March 1, 2021

https://doi.org/10.51238/ISJS.2019.01

Provided in Open Access by the Institute for Advanced Jesuit Studies at Boston College.

The Institute of Jesuit Sources, specializes in preserving, maintaining, and expanding for scholars around the world important texts and studies in Jesuit history, spirituality, and pedagogy.

Visit our website at https://jesuitsources.bc.edu 


\title{
The Voices of Memoria: \\ Diaria, Historiae, and Annuaria as Records of Experience in the Pre-suppression Society
}

\author{
PAUL SHORE
}

One or more underlying values or principles may lie behind many of the documents produced by the pre-suppression Society, the identification of which can aid us in understanding and making use of these documents. ${ }^{1}$ This essay will argue that key to an understanding of the culture of that Society is the idea of memoria. $^{2}$ Memoria can be identified with three aspects of Jesuit activity: Eloquentia, missio, and veneratio (eloquence, mission, and veneration). Cypriano de Soáres (1524-93) argued that memoria was an integral part of eloquentia, and thus, at the center of the Society's educational program: "Non enim solùm rerum, sed etiam verborum ordinem præstat, \& propemodum infinita complectitur" ([Memoria $]$ is the great tool for retaining not only the order of words but also of things and can embrace almost everything). ${ }^{3}$

In its most elevated and self-conscious forms, memoria as part of eloquentia reinforced the institutional history of the Society in ritual, performance, and in widely distributed publications. But the memoria of a specific Jesuit community could be preserved through less ambitious documents that might still contain flashes of eloquentia, or at least pithy observation. What follow are a few observations about three of these humbler genres as they appeared in the pre-1773 Society: the diarium (diary), the annuarium (annual summary), and the historia domus (history of the [professed] House) or historia collegii (history of the collegium).

The term diarium can refer to several categories of recordkeeping. It might on occasion be used to describe a more formally composed document, as when the Jesuit mission to the court of Augustus the Strong in Dresden recorded a diarium seu protocollum (diary or protocol) for the years 1710 to $1721 .{ }^{4}$ A diarium might also deal exclusively with economic matters, as did the Diarium oeconomi-

\footnotetext{
${ }^{1}$ Lynn Whidden provided editorial assistance. Thanks also to Molnár Antal for sharing his research.

${ }^{2}$ See Paul Shore, Narratives of Adversity: Jesuits in the Eastern Peripheries of the Habsburg Realms (1640-1773) (Budapest: Central European University Press, 2012), 178-84.

${ }^{3}$ Tabulae rhetoricae Cypriani Soarii [...] (Venice: Ex officina Damiani Zenarij, 1589), 35.

${ }^{4}$ Janice B. Stockigt, Jan Dismas Zelenka (1679-1745): A Bohemian Musician at the Court of Dresden (Oxford: Oxford University Press, 2000), xix.

https://doi.org/10.51238/ISJS.2019.01

(C) Institute of Jesuit Sources, 2021
} 
cum collegii Cassoviensis societatis Jesu, ab anno 1709-1711, composed for the Košice community. ${ }^{5}$ Students might also keep diaria. Finally, in a few rare instances, diarium could refer to the record kept by a single identifiable Jesuit, such as Melchiorre Valpredosa ${ }^{6}$ or Murin Andras, who kept a record of his travels in Hungary filled with details of the hardships he underwent. ${ }^{7}$

This essay will not focus on this last category but acknowledges that the existence of such personalized diaria could have influenced the composition of other recordkeeping categories of the same name.

The more elaborated diaria detailed the visits of notables and the internment of distinguished laypersons, such as Anna Rezlerowa, who was buried in the Jesuit church in Kraków in $1606 .{ }^{8}$ But a diarium did not always record good or edifying news. At the same professed house in Kraków, a diarium entry acknowledged the authorship of the hugely damaging Monita secreta (Secret instructions): "Prodidiit eodem mense [July 1615] famosus ille contra Societatem libellus cum illo titulo: Monita privata Soc. Jesu [...] brevi certo constitit D. Hieronymo Zahorowski fuisse scriptum" (In this month [July 1615] appeared the famous little book against the Society with the title The Secret Instructions of the Society of Jesus. Hieronymus Zahorski is regarded as its author). ${ }^{9}$

By 1751, the Society had maintained a presence in Târgu Mureș, Transylvania, for almost a century and had recently opened a school with four grades. ${ }^{10}$ But relations between the fathers and the townspeople were not entirely cordial. We gain a glimpse of these strained relations in this entry from the diarium missionis: "Majus [1751] Hoc mense post longam cum civibus altercationem tandem ad locum aedificandae molae opportunisserent vehi ceperunt ligna" (May [1751]: This month, after a long altercation with the citizens, we had the chance to get the wood needed to build the barricade). ${ }^{11}$ Was this "mola" a barricade in front of the

\footnotetext{
5 Edit, “Ab88 Diarium oeconomicum collegii Cassoviensis societatis Jesu, ab anno 1709-1711”; https://edit.elte.hu/xmlui/handle/10831/32865?locale-attribute=en (accessed August 12, 2020). Records of the Jesuit pharmacy are also found in this document: Sági Erzsébet, "Az egykori kassai jezsuita gyógyszertár," Gyógyszerészettörténeti Közlemények 42 (1998): 416-18.

6 Silvia Mostaccio, Early Modern Jesuits between Obedience and Conscience during the Generalate of Claudio Acquaviva (1581-1615) (Farnham: Ashgate, 2014), 16.

${ }^{7}$ Murin's entry for January 13, 1710 describes his lack of food and wine and the necessity of begging. Molnár Antal, "Murin András jezsuita szerzetes szekszárdi útinaplója 1710-ből," Levéltári Közlemények 77, no. 1 (2006): 105-39, here 121.

${ }^{8}$ Józef Szujski et al., eds., Scriptores rerum Polonicarum: Historici diarii domus professae S.J. ad S. Barbara Cracoviae annos unidecim 1609-1619 (Kraków: Nakladem Akademii umiejętności, 1889), 6; http://dir.icm.edu.pl/Scriptores_Rerum_Polonicarum/Tom_14/IX (accessed August 12, 2020).

${ }^{9}$ Der Jesuit in seiner Blösse oder die entdeckten Geheimnisse des Jesuiter-Ordens (Paris, 1763), 167.

${ }^{10}$ Gyenis András, Régi jezsuita rendházak; https://mek.oszk.hu/00000/00014/00014.htm (accessed August 12, 2020).

${ }^{11}$ Diarium missionis Maros-Vásárhelyensis, S.J. T. III. AB A. 1741-63 National Library of Romania-Batthyaneum, Alba Iulia, Romania, 135. Manuscriptorium; http://www.manuscriptori-
} 


\section{Engaging Sources}

Jesuit residence? The following month, we read: "Tenent hac mense opera ad mola' Varis [?] varia adjumenta prostant. Tum in vecturis tum in incutiendis palis ingentibus Calvinistis [...]" (More work was done on the barricade. Various additions were completed, since the Calvinists were going to threaten [us] with huge stakes that they would carry).

Diaria might also record misfortunes and serious setbacks. Jesuits were forced to leave Levoča (Lőcse, Leutschau, Leutschovia), a town in Upper Hungary, in January of 1707, with one of their brethren, Stephanus Pethö, left behind because he was dangerously ill. The following month, Pethö died. The Jesuits could not return to this religiously divided community of Upper Hungary for three years. ${ }^{12}$ A less calamitous but still annoying development afflicted the community in Uhzhororod (Uzhgorod, Ungvár, Ungwar) early on the morning of December 17, 1714: "Ex defecto horlogij surrexit ante 2ndam horam nocturnam [...]" (Because of a mechanical problem with the clock, the community rose before two in the night $[\ldots]) .^{13}$

Many of the diaria from communities in the northern and eastern Austrian province consist of brief daily entries, sometimes incomplete sentences, never appearing in the vernacular, often showing signs of having been written in haste, and collected chronologically into a small codex. The audiences for such Jesuit diaria are not always easy to discern. When the entries focus on finances or on other household matters expressed quantitatively, we may suppose that these records may have been consulted in later years by those with the same responsibilities as those of the original writers, with the purpose of estimating current costs and needs. Yet a significant number of the diaria from Upper Hungary cannot have served this function. In fact, elements of diaria entries may have fulfilled the role of something close to personal diaries, which were not allowed or at least discouraged in most Jesuit communities. The occasionally highly subjective and emotionally tinged tone of these entries suggest that the anonymous writers could have used them for expressing feelings that could not be articulated in other ways.

Yet these Jesuit diaria were never private in the way one's own personal diary is at least supposed to be. While they were not daily chronicles whose contents would be announced to the community, and may even have been under lock and key, these records seemingly could be accessed for the practical purposes just

\footnotetext{
um.com/apps/index.php?direct=record\&pid=NLR NLORB_MS_XI_99 2ZKCQ8E-ro\#search (accessed August 12, 2020).

${ }^{12}$ Historia et diarium convictus Leutschoviensis, 425, cited in Monika Bizoňová, "Society of Jesus and Counter Reformation in Spiš Region," in Frühneuzeitforschung in der Habsburgermonarchie: Adel und Wiener Hof-Konfessionalsierung-Siebenbürgen = Koraújkorkutatás a Habsburg monarchiában, ed. István Fazekas et al. (Vienna: Inst. für Ungarische Geschichtsforschung, 2013), 185-99, here 197.

${ }^{13}$ Diarium collegii Ungvariensis Soc. Jesu Cat. Lib. Man. II, I, 126 Jezsuita Levéltár, Budapest, fol. $249^{\mathrm{v}}$.
} 
noted. Nor could these records ever be as anonymous as public restroom graffiti: any reader within the community (which might number only a handful of men) would have little trouble determining who had made the entries, if indeed that information was not already generally known. Sometimes the events recorded would have been common (if scandalous) knowledge, as when in 1693 at the residence in Banská Bystrica (Besztercebánya, Neusohl) the cook was arrested for beating the brother in charge of the household with a stick. ${ }^{14}$ And I cannot resist mentioning an entry from the diarium of the Sárospatak (Hungary) residence dated 1703, which complains "Coquus iter[um] porcus ebrius totus" (The pig of a cook was dead drunk again). ${ }^{15}$ On a far more uplifting note, the entry for June 25(?), 1560 in the diarium of the Collegium ad St. Clementem in Prague we find that "fratres venerunt[?] in carceres et hospitalia" (coadjutors visited prisons and hospitals). ${ }^{16}$ Jesuit engagement with local cultures is documented in an entry in the diarium of the Levoča community from 1674 that records that students sang in Slovak during a ceremony. ${ }^{17}$

Other times, a diarium entry raises more questions than it can answer. An entry in the diarium of the collegium in Košice (Kassa, Kaschau, Cassovia) for August 5, 1702 relates how the community sent "our doctor" to an officer who had been wounded in a duel with another soldier. However, no medicus is listed among the personnel of the community. ${ }^{18}$ The "salii" mentioned as part of an Epiphany procession that also included "Bacchos" in a 1737 entry in the diarium of the community in Târgu Mureș (Marosvásárhely) form another mystery. ${ }^{19}$ Were they dancing or leaping as had the ancient Roman youths of the same name?

At the far edge of this genre, we find references to a "dennik" or diarium from the Jesuit community in Staré Hory (Slovakia) that listed prophecies attributed to a Franciscan. These included the prediction that in 1790 "Africa will burn and Rome will be surfeited with blood." 20 This document, cited in a nine-

\footnotetext{
${ }^{14}$ Shore, Narratives, 182.

${ }^{15}$ Historia residentiae Patakiensis S.J., MS 2, 1, Ab 96, fol. 67 , Eötvös Loránd Tudományegyetem Egyetemi Könyvtár (hereafter ELTEK).

${ }^{16}$ Diarium collegii Societatis Jesu Pragae ad sanctum Clementem 1560-1583, fol. 27 , DC 3 20; Královská kanonie premonstrátů na Strahově, Prague; http://www.manuscriptorium.com/apps/index.php?direct=record\&pid=AIPDIG-KKPS_DC_III_20_42DVIN2-cs\#search (accessed August 12, 2020).

${ }^{17}$ Diarium residentiae Societatis Jesu Leuchoviensis, cited in Monika Bizoňová, "Spoločnost' Ježišova a jej účinkovanie v Levoči," Historia ecclesiastica 4, no. 2 (2013): 104-24, here 108.

${ }^{18}$ Paul Shore, "Mission Mostly Accomplished: Narratives of Jesuit Success and Failures in Hungary and Transylvania, 1640-1772," Publicationes Universitatis Miskolciensis: Sectio philosophica 15, no. 2 (2009): 179-92, here 184.

${ }^{19}$ Kllián István, "Karácsony és vízkereszt néhány jezsuita templomban a 18. században," in $A z$ áhitat nem hivatalos alkalmai és formái az 1800 elötti Magyarországon, ed. Bogár Judit (Piliscsaba: Pázmány Péter Katolikus Egyetem Bölcsészet- és Társadalomtudományi Kar, 2013), 119-31, here 129.

${ }^{20}$ See Shore, Narratives, 179.
} 


\section{Engaging Sources}

teenth-century article that does not indicate its provenance, seems unlikely to have been an institutional diarium but, if genuine, may have been the rare private musings of an unknown Jesuit, although other explanations are also possible.

The writers of diaria such as these could be reasonably sure that their writings would not find their way into the network of published Litterae annuae and that they would not circulate in manuscript form to other Jesuit communities. (This writer has never found direct or indirect evidence that any of these Hungarian diaria were copied.) Broadly speaking, the functions of diaria were different from those of letters that held the Society's communication network together. ${ }^{21}$ In many, but not all instances, Jesuits shared information in correspondence that would be of value to other Jesuits and possibly the wider world as well: useful and edifying, and perhaps both. Diaria by contrast more generally fulfilled the role of receptacle of the memoria of a community.

With these facts in mind, here are several observations about the function of these records within Jesuit communities. First, despite the tendency toward uniformity in many external aspects of life in the baroque Society, there is no reason to suppose that the personalities and ranges of action of the men writing the diaria manifested themselves in a uniform way. A temporal coadjutor, for example, with many years of service in the community, and having accrued the respect and leeway coming with these years, might write with more freedom than a recently arrived scholastic assigned the task of recording daily happenings. Command of Latin might shape what was written, and how. The timing and frequency of entries also influenced the document. As Kilián István points out, a diarium might even record events on an hour-by-hour basis. ${ }^{22}$

Certain themes run like a leitmotif through these records. Fear was a common theme of diarium entries during the Rákóczi rebellion, which lasted from 1703 to 1711. As Francis II Rákóczi's (r.1704-11) troops approached Túrócz (Turiec, Turz) in Upper Hungary, an anonymous Jesuit wrote: "Eramus tota die et nocte, in vigiliis cum maximo timore [...]" (We were there all day and night, and in the greatest fear [...]). ${ }^{23}$ Three years earlier in Sárospatak, facing the same army, a Jesuit wrote "timor undiq" (fear everywhere). ${ }^{24}$ Along with present fear, past misfortune might be related in a historia. Recalling in 1644 the expulsion of Jesuits eleven years earlier, the historia of the Erfurt collegium records, "Ac-

\footnotetext{
${ }^{21}$ The lineaments of Jesuit correspondence culture are sketched in Noël Golvers, "Savant Correspondence from China with Europe in the 17th-18th Centuries," Journal of Early Modern Studies 1 , no. 1 (2012): 21-41.

${ }^{22}$ Kllián István, "Új források az egri, a marosvásárhelyi és a győri jezsuita rendház történetéhez (17-18. század)," in Amicitia: Tanulmányok Tüskés Gábor 60. születésnapjára, ed. Lengyel Réka (Budapest: Reciti, 2015), 79-91.

${ }^{23}$ Diarium residentiae S.J. Thurosziensis ab 1704, 17 November 1709, MS 1, Ab 111, fol. 125 , ELTEK.

${ }^{24}$ Historia residentiae Patakiensis S.J. MS 1, Ab 96, fol. 86 , ELTEK.
} 
cinctis porro itineri Patribus ita valadictu[m] à sectarijs, Jte nihil efferte, et in aeternu[m] ne redite, etc." (Surrounded by the sectarians all along the route, the fathers received a farewell of "Go, take nothing with you and never come back, etc.!"). ${ }^{25}$ Collective memoria linked these recent and less recent experiences. When other records are lacking, diaria provide unique documentation of important events in a community. On March 19, 1673, during the Lenten season, the syntaxis class of the collegium in Levoča staged "Christus Fortis Bellator in Samsone Expressus" (Christ, a Mighty Warrior, Shining Forth in Samson), a play about which we have no further information. ${ }^{26}$ The growth of the library of the Cluj (Kolozsvár, Klausenburg, Cluadiopolis) community is charted in the Diarium expositorum residentiae Claudiopolitanae Societatis Jesu. ${ }^{27}$ Clues to the aesthetic sensibilities of Jesuit communities are also found in the chronograms employed in titles of diaria, such as at the commencement of the diarium of the Sárospatak residence for 1711 (the year that Jesuits were able to return to this town). ${ }^{28}$ The persistence of baroque ceremonial and ritual on the eve of the suppression of the old Society is evident in a diarium description of a procession in Győr (Raab, Ráb, Jaurinium) in 1771 in which a medieval relic was carried by eight priests with soldiers and torchbearers in attendance. ${ }^{29}$ It is hard not to smile at the mishap described in the April 18, 1710 entry of the diarium of the Vilnius collegium: during a Good Friday performance set at the Lord's sepulcher, special effects ("per ignes missiles") went haywire, and among "alia damna" (other casualties), Father Prefect's beard was set afire. ${ }^{30}$

Yet the rhythms of day-to-day life are also suggested by entries in the diary of the residence of Cieszyn (Teschen, Tessin), Silesia (now in Poland): on August 17, 1707 occurred "nihil speciale" (nothing special), and August 2 was notable only for "media die recreatio" (midday, recreation). ${ }^{31}$ At the collegium of Por-

\footnotetext{
${ }^{25}$ In Holger Berg, Military Occupation under the Eyes of the Lord: Studies in Erfurt during the Thirty Years War (Göttingen: Vandenhoeck \& Ruprecht, 2011), 276.

${ }^{26}$ Staud Géza, A magyarországi jezsuita iskolai szinjátékok forrasai, 3 vols. (Budapest: Magyar Tudományos Akad. Könyvtárának Kiadása, 1984-88), 2:441.

27 “A kolozsvári jezsuita Akadémia könyvtára (1693-1773)"; http://mek.oszk.hu/03100/03186/html/gyorgy15.htm (accessed August 12, 2020).

${ }^{28}$ Gyulai Éva, “A jezsuiták visszatelepedése Sárospatakra 1711-ben,” Történelem és Muzeológia-Internetes Folyóirat Miskolcon 3, no. 1 (2016): 120-31, here 123.

${ }^{29}$ Kerny Terézia, "Két 18. századi győri egyházi ünnepségröl: Adalékok Győr barokk Szent László tiszteletéhez," in Ritus és Ünnep, ed. Barna Gábor and Gyöngyössy Orsolya (Szeged: Néprajzi és Kulturális Antropológiai Tanszék, 2010), 163-78, here 171.

${ }^{30}$ Diarium collegij Societatis Iesu ab anno 1710 ad anni 1723 septembrem exclusive, fol. 4, Vilniaus universitato biblioteka, 4; http://www.atmintis.mb.vu.lt/kolekcijos/VUB01_0004243990000 (accessed August 12, 2020). Here, we catch a glimpse of priestly grooming at odds with an overwhelmingly clean-shaven age.

${ }^{31}$ Diarium residentiae S.J. Teschinensis ab anno 1707-1721, SZ DD 194 a, Biblioteka Śląska w Katowicach, fols. 23, 21, Biblioteka Ślaska w Katowicach, 39; https://www.sbc.org.pl/dlibra/publication/41632/edition/383 (accessed August 12, 2020).
} 


\section{Engaging Sources}

rentruy, now in Switzerland, on February 27, 1671, the most memorable event of the day was the donation of a cask (doliolum) of salmon by a gentleman named Trutwiller. ${ }^{32}$ In April of the same year, roast hares and "three measures of wine" were enthusiastically received by the same community. ${ }^{33}$ Fasts and vigils were likewise recorded in the Ciszyn diarium, as in the days immediately preceding Christmas $1715 .{ }^{34}$

Jesuit perceptions of their neighbors crop up in historae domus: one such document from Eger, Hungary, notes that "cives, si Hungari sint, plerosque esse pauperes; si Germani, paucos [...]" (the citizens who are Hungarian tend to be poor; the Germans, less so [...]). ${ }^{35}$ These observations can go as far as denunciations of local clergy who have surrendered to avarice, as did one Nicolaus Jeziorkowitz, who in 1677 seduced parishioners in a church close to Piekary (Piekar, Piekarum), Silesia, with faked miracles associated with an image of the Virgin. ${ }^{36}$

The seventeenth-century diaria of the gymnasium in Munich contain both spelling errors and neologisms to accommodate changing circumstances, a particularly memorable example being supremus locum tenens (the highest one holding the place) for the German Oberstlieutenant. ${ }^{37}$ There are instances when the intent and motivation of the writer of a diarium remain obscure, though they may have been much clearer to members of the community. The chronicler of the Jesuit community in Levoča, in what is now east central Slovakia, referred to a thief of no identified confession on his way to execution as a "martalus," a Latin term for a martin or weasel. ${ }^{38}$ On other occasions, the technical Latin term can be identified clearly, such as the word for Greek fire. Thus we should be careful when making generalizations about the conditions under which these records were written.

But some generalizations are nonetheless in order. When faced with unusual or stressful events such as we have just heard about-violence, natural disasters, or epidemics - the diaria could serve as an expression of those generally held emotions that did not fit easily into the rituals and performances common to

32 E-Codices: Diarium collegii Bruntrutani Soc. Jesu ab anno 1671, A2626bis-2, fol. 6, Porrentruy, bibliothèque cantonale jurassienne; https://www.e-codices.unifr.ch/en/bcj/A2626bis-2/bindingE/0/Sequence-1988 (accessed August 12, 2020).

${ }_{33}^{33}$ Diarium collegii Bruntrutani, April 5, 1671, fol. 12.

${ }^{34}$ Diarium residentiae S.J. Teschinensis, December 4, 1715, fol. 439.

${ }^{35}$ Undated (c.1710?) excerpt from Historia domus residentiae Agriensis Societatis Jesu. I. 16871738, cited in Nagy Árpád, “Az egri volt jezsuita („Magyar Király”) patika története. 1713-1773,” Archivum: A Heves Megyei Levéltár közleményei 1 (1973): 31-41, here 36.

${ }^{36}$ Historia residentiae, 3.

${ }^{37}$ Wolfgang Bauer, Aus dem diarium gymnasii S.J. Monacensis (Munich: Gotteswinter und Mössl, 1878), 26.

${ }^{38}$ Diarium collegii Leutschoviensis, August 30, 1700, fol. 247v, Jesuitica P. 478, Microfilm 51261, Magyar Országos Levéltár, Budapest. See also Paul Shore, “'In carcere; ad supplicium': Jesuit Encounters in Prison and in Places of Execution; Reflections on the Early Modern Period," European Review of History 19, no. 2 (2012): 183-200. 
Jesuit life. This admittedly is an assertion that cannot readily be tested. Yet in a culture such as the Society's, which placed such emphasis on writing and on careful observation, and also had to function as a community of men standing together in an often hostile environment, the use of less formal and non-circulating writing to express generally held sentiments is not improbable. Entries such as the ones just mentioned are notably free of the formulaic Latinity found in more widely circulating documents. Simultaneously, these entries could be an expression of individual experience. It is also likely that on occasion these anonymous records were compiled by brothers or scholastics.

Where the Jesuit community was very small, this expression of emotion and conviction might be that of an identifiable priest. In Târgu Mureș, during the Christmas season of 1736, Father János Vass was approached by the wife of a resident who wanted to borrow the priest's vestments so that her husband could play the role of St. Nicholas "ad terrificandos pueros" (to scare the boys). ${ }^{39}$ The writer of the diarium of the community, who was most probably Vass himself, reported that this request had been firmly rejected. A year later, when a Calvinist resident of the same town was being pressured to convert, he responded "I will not become a devil." 40 The man's exact words were recorded (again, presumably by Vass) in Hungarian, perhaps because the statement was too blasphemous to be entered in Latin. Or was Vass (whose surname suggests a possible Germanspeaking background) expressing his feelings toward Hungarian Calvinists more generally? Or perhaps the resisting Calvinist's words were something Vass wished to reflect upon later.

The historia domus or historia collegii, ${ }^{41}$ like the diarium, was not intended for publication, but these documents constituted a more formalized and generally more detailed record of the activities and experiences of a community and often followed an organizational pattern (sometimes with numbered sections) shared across the Jesuit world. They also reflect a desire to keep records in a Latin echoing the language of Cicero and Augustine while carefully noting events worthy to be reported in other documents "up the food chain," as it were of the Society's communication network. The definition of worthy events evolved over time. In the seventeenth century, such alleged occurrences could at times be stunning. Among the miraculous cures reported in the Historia residentiae ac templi (History of the residence and church) in Piekary, Silesia, in 1681, were "5. a morte

\footnotetext{
${ }^{39}$ Paul Shore, "Jesuit Missions and Schools in Eighteenth-Century Transylvania and Eastern Hungary," in Lesestoffe und kulturelles Niveau des niederen Klerus: Jesuiten und die nationalen Kulturverhältnisse: Böhmen, Mähren und das Karpatenbecken im XVII Jahrhundert, ed. István Monok (Szeged: Scriptum Rt., 2001), 101-18, here 107.

${ }^{40}$ Shore, "Jesuit Missions," 110.

${ }^{41}$ These terms may be conflated in secondary literature, e.g., Stefan Tilg, Die Hl. Katharina von Alexandria auf der Jesuitenbühne (Tübingen: Max Niemeyer, 2005), 464.
} 
revocatus" (five brought back to life). Scandal is largely absent, although reports of the refutation of calumniae (calumnies) against the Society are common. ${ }^{42}$ In the decades immediately before the suppression, these records suggest changes in the intellectual culture of Jesuit communities. The development of a Jesuit library with significant holdings in the vernacular, in this case Polish, is attested in the Historia residentiae of the Daugavpils (Dynaberg, Daugpily) community in the middle of the eighteenth century. ${ }^{43}$

These historiae were by no means merely improvised. As early as 1598, Claudio Acquaviva (in office 1581-1615) had written to provincials outlining his intent to see the composition of a general history of the Society, and in the opinion of Claudio Ferlan, it was here that the historia domus and the historia collegii were born. ${ }^{44}$ Carlo Storani, the provincial of the Roman province, provided the Ragusan Jesuit Šimun Pavao (Simone Paolo) Capitozzi (1670-1753) a scheme for composing these documents in $1732 .{ }^{45}$ The entry for 1704 of the historia of the Jesuit collegium in Cluj, Transylvania, took careful note of conversions made, recording the conversion of "Singara una 35 annis" (One Roma woman, thirty-five years old). ${ }^{46}$ This year was marked by the rebellion of Francis II Rákóczi and the relief of the siege of the town. Three years later, the historia records the number of times Communion was distributed: 6,590. Other details of community life come to light in these documents: a church service held in 1709 to beseech God to deliver Cluj from the plague featured trumpets and tympani. The inclusion of obituaries and the entry of marginalia in a later hand show that the Cluj historia was consulted and served as a way of preserving the memoria of the community. Relations between Jesuit institutions and thus between major urban centers were also reported in historiae collegii. The advancement of theology students from Buda to Trnava or Vienna from 1743 to 1747 is recorded in the Historia Collegii Budensis of these years.

A historia collegii or domus might record musical and dramatic performances, as in Brno in the middle of the seventeenth century, where a sepulcrum

\footnotetext{
${ }^{42}$ Historia residentiae ac templi Societatis Jesu Piekarii (1678-1716) (Katowice: Nakładem Towarzystwa Przyjaciół Nauk na Śląsku, 1932), 23.

43 Andrea Mariani, "Jezuici w Inflantach i w Kurlandii (1700-1773): Między wielką polityką a elitą lokalnąi," Zapiski Historyczne 77, no. 4 (2012): 113-38, here 134n113.

${ }^{44}$ In a few cases, the composer of a historia collegii is known: Georgius (György) (Dobronoki (1588-1649) is credited as the author of the Historia collegii Soproniensis. Johann Nepomuk Stöger, Historiographi Societatis Iesu, ab eius origine ad nostra usque tempora (Regensburg: Libraria Coppenrathiana, 1851), 41.

${ }^{45}$ Teodora Shek Brnardić, "From Acceptance to Animosity: Trajectories of Croatian Jesuit Historiography," Jesuit Historiography Online, ed. Robert A. Maryks; https://referenceworks.brillonline.com/entries/jesuit-historiography-online/from-acceptance-to-animosity-trajectories-ofcroatian-jesuit-historiography-COM_192535?lang=fr\#note38 (accessed August 12, 2020).

${ }^{46}$ Historia collegii Claudiopol, Országos Széchenyi Könyvtár (hereafter OSzK) 2039/FMI/1608 57.
} 
included instrumental music and tableaux vivants. ${ }^{47}$ We catch a glimpse of the emotional qualities of the devotional life of a community in this account (translated here from the Latin) of the celebration held in the Jesuit church in Cambrai following the canonization of Ignatius of Loyola and Francis Xavier in 1622:

Never had our church appeared with more august brilliance: two kinds of chapels were erected on each side of the main altar, and each one had a throne of saints [of] such height that it loomed over the first floor of the church. Candles shone on every conceivable part of a structure filled with tiers of seating; above, there were three triumphal arches and ingenious shadows filling the souls of those who were praying with a holy horror [sacer horror] and a religious feeling. ${ }^{48}$

The anonymous writer of the historia domus in which this description appeared is conveying pride of accomplishment, as well as the interplay of light and subjective experience in the cultivation of an emotionally saturated encounter with the sacred - and even the supernatural. Unlike the laconic entries in many diaria, this passage was probably intended to be read by others (perhaps aloud), even if it was not to be published: here, the drive toward edification that pervaded so much of the writings of the old Society is evident. Historiae domus are also valuable sources for details of the sodalities that Jesuits promoted, such as one in early eighteenth-century Genoa consisting of "fattorini" or deliverymen. ${ }^{49}$

Diaria might also recount celebrations, and sometimes note who was invited but did not come. ${ }^{50}$ We also catch glimpses of creative activity from the lists of members of a community. In 1663, the Jesuit collegium at Hradec Králové included temporal coadjutor Christophorus Reichel (or Reiffel), who was described

${ }^{47}$ Tomasz Jeż, Kultura muzyczna jezuitów na Ślasku i ziemi kłodzkiej (1581-1776) (Warsaw: Wydawnictwo Naukowe Sub Lupa, 2013), 196.

${ }^{48}$ Cited in Ralph Dekonnick and Annick Delfosse, "Sacer horror: The Construction and Experience of the Sublime in the Jesuit Festivities of the Early Seventeenth-Century Southern Netherlands," Journal of Historians of Netherlandish Art 8, no. 2 (2016); https://jhna.org/articles/sacerhorror-construction-experience-sublime-jesuit-festivities-early-seventeenth-century-southernnetherlands/ (accessed August 12, 2020).

${ }^{49}$ Edoardo Grendi, In altri termini: Etnografia e storia di una società di antico regime, ed. Osvaldo Raggio and Angelo Torre (Milan: Feltrinelli, 2004), 76.

${ }^{50}$ The parish priest of the northeastern Hungarian village of Tállya was invited to a celebration in Sárospatak of the feast day of St. Ignatius in 1696, and when he did not attend, this was seen as important enough to be mentioned in the community's diarium. Gyulai Éva, "A sárospataki jezsuiták és a hegyaljai plébániák a 17. század második felében,” in Katolikus megújulás Folia Collecta Északkelet-Magyarországon, ed. Irén Szabó (Sárospatak: Római Katolikus Egyházi Gyüjtemény 2014), 110-41, here 135. 


\section{Engaging Sources}

as a pictor (i.e., an artist or painter).$^{51}$ Diaria can shed further light on the activities of these coadjutors, often overlooked in other documents: for example, in 1739, an operarius (laborer?) named Gress traveled with Father Andreas Spangár (1678-1744) from Rožňava (Rozsnyó, Rosenau, Rojna [Turkish], Rosnavia) to a chapel near a spring named for Mary Magdalene. ${ }^{52}$

A historia domus might be copied, with these copies distributed, although we do not know how common this practice was; the Historia domus Antverpiensis (History of the professed house in Antwerp) 1562-1618 survives in three versions, one of which is now in Rome. ${ }^{53}$ Such records are frequently the only surviving documentation of Jesuit dramas. ${ }^{54}$ The specific, year-by-year assignments of Jesuits are likewise sometimes documented more clearly than in other records. ${ }^{55}$ The curious and even inaccurate could find their way into these documents: in the historia domus for the community in Prešov (Eperjes, Preshau) for the years 1651-89, we read of the conversion (from Islam?) of a "faemina turcica poppae budensis uxor" (Turkish woman, the wife of an Orthodox priest). ${ }^{56}$ Perhaps she was a wife of an imam? Or the Muslim-born wife of an Orthodox priest? Events of particular significance could interrupt the usual organization of the document. The following entry in the historia domus professae of Vienna reported a major earthquake:

Eiusdem 15. Septembris [1590] circa horam 5 vespertinam incaepit esse terrae motus mediocris, maior hora 6. et maximus post mediam noctem. Concussa sunt templa, turres, domus, quarum una penitus corruit et oppressit undecim homines et sumitas turris nostrae decidit. In mane hora 7. iterum fuit terrae motus [On the fifteenth of the same September [1590] around five in the evening, a moderate earthquake began; a bigger one fol-

${ }^{51}$ Klára Zářecká, "Diarium collegii Reginaehradecensis (1662-1666): Historiografický pramen z prostředí Tovaryšstva Ježíšova," Folia historica Bohemica 31, no. 2 (2016):199-236, here 21011.

${ }^{52}$ Knapp Éva, "Spangár András és a Magyarok bibliotékája: Fejezet a 18. századi historia litteraria történetéből," Irodalomtörténeti Közlemények 117, no. 3 (2013): 247-80, here 260n101.

${ }^{53}$ Jeanine de Landtsheer, "Historia domus Antverpiensis: De jezuïeten te Antwerpen van vóór het prille begin tot het eerste kwart van de zeventiende eeuw," De zeventiende eeuw 14 (1998):15-25, here 15; https://www.dbnl.org/tekst/_zev001199801_01/_zev001199801_01_0003.php.

${ }^{54}$ Goran Proot and Leo Egghe, “'An almost innumerable number of theatre plays': The Estimation of Editions on the Basis of Retrieved Copies; Printed Programmes of Jesuit Theatre Plays in the Provincia Flandro-Belgica (before 1773)," 1; https://pdfs.semanticscholar.org/8d73/8c66589da0463fdf6ee3848a8e140f76a701.pdf (accessed August 12, 2020).

${ }^{55}$ Peter Pázmány, for example, served as confessor and theologus in Bratislava to the Hungarian primate Ferenc Forgách for several years after 1607. Kádár Zsófia, "A pozsonyi jezsuita kollégium mint összetett intézmény a 17. században," Történelmi szemle 60 (2018): 237-82, here 239. Intriguingly, Jesuits traveled from Vienna to Albania in 1689. Paul Shore, "Contact, Confrontation, Accommodation: Jesuits and Islam, 1540-1770," Al-Qantara: Revista de estudios Árabes 36 , no. 2 (2015): 429-41, here 436.

${ }^{56}$ Shore, Narratives, 100. 
lowed at the sixth hour and the greatest took place after midnight. The church, the towers, and the houses were all hit, one of which was almost completely destroyed, and twelve people were crushed. The top of our tower fell down. The next morning at the seventh hour there was another earthquake]. ${ }^{57}$

A different sort of earthquake took place in Sárospatak during the ascendency of the Rákóczi uprising in 1704. A Reformed school was re-establishing its library and demanded that the Jesuits return books that they had confiscated, along with a bell. The writer of the Historia domestica residentiae observed that "quae Campanae redditio non tam difficilis accidit, quam librorum" (handing over the bell was not as hard as handing over the books). ${ }^{58}$ Less traumatically, the laying of the cornerstone of the Royal Palace in Buda in 1749 was described in the historia collegii in that city. ${ }^{59}$

Unanticipated themes might impose themselves on the composition of these chronicles. The historia collegii narrative of the year 1710 in Cluj is broken by the boldly written words "In Tempore Pestis" (In the time of plague). The following narrative describes the closure of the Society's school and the heroic piety of the students who remained in the community. ${ }^{60}$ Stock phrases are in evidence, but the obituaries that follow suggest the scope of the disaster. The emotional tone is restrained yet still perceptible. A few years later, in better times, the title of the entry for 1714 is embellished with cheerful curlicues that seem almost medieval. ${ }^{61}$

A close relative of the historia domus is the diairium ministri (diary of ministry), which recorded data of more than ephemeral significance. The diarium ministri of the collegium in Ljubljana listed the names and duties of the members of the community for 1751 in a formalized fashion very similar to what appears in a historia collegii or in litterae annuae. ${ }^{62}$ In much the same way, the diarium do-

\footnotetext{
${ }^{57}$ Historia domus professae, tom. 1, fol. 46 $\mathrm{v}$, in Christa Hammerl and Wolfgang A. Lenhardt, "Erdbeben in Niederösterreich von 1000 bis 2009 n. Chr.," Abhandungen des geologischen Bundesanstalt 67 (2013): 57.

58 Historia domestica residentiae S.J. Patakiensis, 1. 139, cited in Magyarországi jezsuita könyvtárak 1711-ig I Kassa, Pozsony, Sárospatak, Turóc, Ungvár; http://hozir.org/hu-issn-02308495-magyarorszgi-jezsuita-konyvtrak-1711-ig-i-ka.html?page=23 (accessed August 12, 2020).

59 Kelényi György, "A budai királyi palota építésének története a XVIII. században," Tanulmányok Budapest múltjából 29 (2001): 217-40, here 218.

${ }^{60}$ Historia collegii Claudiopol, OSzK 2039/FMI/1608, 91. Thirty years later, plague struck the Society's collegium in Buda, and the school was closed when the number of students fell by half. Historia collegii Budensis S.J. ab anno 1737 usque ad annum 1771 (Ab 84), cited in Madzsar Imre, “A budai jezsuita akadémia története,” Magyar paedagógia 35 (1926): 1-12, here 6.

${ }^{61}$ Historia collegii Claudiopol, OSzK 2039/FMI/1608, 121.

62 Stanislav Južnič, "Knjižničarji in knjige o matematičnih vedah v knjižnici ljubljanskega jezuitskega kolegija," Knjižnica 49, no. 3 (2005): 155-82, here 157. While we cannot know the organization of lost diaria, that chroniclers such as Simon Capitozzi, whom we have already met, used such diaria to create institutional histories suggests that at least some of these diaria were
} 


\section{Engaging Sources}

mus professae of Kraków resembles a historia domus more than some of the diaria we have just met. Here, the entries are for specific days but can be separated by weeks or even months. Yet the emotional tone characteristic of the less formally composed diaria seeps through in some entries:

29 Octobris 1599 atrox spectaculum reipublicae Christianae exhibitum, Andreas Bathoreus, cardinalis regis Stephani ex fratre germano nepos, occupata Transylvania, bellum cum Michaele Valacho [...] iniit et in ispa acie fraude suorum Hungarorum proditus profligatus est [...] [On October 29, 1599 was seen a shocking spectacle to behold in a Christian republic: András Bathory, nephew by his brother to King Stephen, was engaged in war with Michael the Valachian [Michael the Brave (1558-1601)] at the time that Transylvania was occupied (...) and while in this same campaign he was bribed by the deceit of his own Hungarians and corrupted $(\ldots)] .^{63}$

Somewhat halfway between the hurried jottings of diaria and the more extended prose exposition of a historia domus is the annuarium, also called an annuae. An example of this much rarer genre also comes from Transylvania, where an account of the Society's mission to Cluj between the years 1655 and 1662 was produced. ${ }^{64}$ This annuarium, which lacks the organization of the historia, includes passages that seem influenced by set pieces describing Jesuit heroism and virtue found in published histories of the Society. Yet there are also glimpses of a premodern world filled with supernatural phenomena, such as visions of cows and bulls spewing blasphemies, experienced by Jesuits and their neighbors. For example, in 1655, demons in the forms of jackdaws and crows were tormenting residents by entering their bodies. Jesuits responded with exorcisms, which seem to have done the trick. This incident is already framed in a way that could aid it appearing later in published or at least circulated Litterae annuae, and we should keep in mind that the annuarium provides only the Jesuit version of events. But here we also have evidence of a potentially shared experience (perhaps involving non-Catholics) of the supernatural, and a reminder of how important this supernatural aspect of life was to the culture of the seventeenth-century Society. On a more prosaic level, this annuarium informs us that the community also employed

systematically organized. Marica Šapro-Ficović and Željko Vegh, "The History of Jesuit Libraries in Croatia: An Overview," Journal of Jesuit Studies 2, no. 2 (2015): 283-301, here 294.

${ }^{63}$ Andreas Veress, ed., Annuae litterae Societatis Jesu de rebus Transylvanicis temporibus Principum Báthory (1579-1613) (Budapest: Institutum Fontium Historicum Hungariae, 1921), 223.

${ }^{64}$ Paul Shore, "Fragmentum annuarium collegii Societatis Iesu Claudiopolitani: The Account of a Jesuit Mission in Transylvania, 1659-1662," Reformation and Renaissance Review 8, no. 1 (2006): 83-106. 
laypersons such as a boy assistant and two mule drivers. Not only would this type of information never find its way into a historia or Litterae annuae but it also sheds light on what was considered important to people on the ground at the time - things far different from what interested Vienna or Rome.

Historiae or annuae might contain elogia for members of the community who had died during the year. Besides the specific details of the deceased's life, desired behavioral and devotional patterns may be discerned in these accounts. ${ }^{65}$ Key facts about the level and type of interaction between Jesuits and the community can also come to light. In Oradea (Nagyvárad, Großwardein, Magno-Varad), an unnamed "Pater Missionarius" (Father Missionary) preached in both Hungarian and Romanian in $1772 .{ }^{66}$ The mention of the second language is noteworthy since very few Jesuits working in this region were fluent in Romanian. Tragedy also haunts the pages of historiae: in Sárospatak in 1679, a "captivum Turcum peste corruptum" (captive Turk, his health ruined by the plague) was converted but died nine hours later. ${ }^{67}$

Thus both historiae and annuaria served as vehicles for self-presentation to the larger Jesuit world, but also for self-presentation to the Jesuit communities themselves. By the time that the documents I have introduced here were being written, the Society already had more than a century of history writing under its belt. The writers of historiae and annuaria might well have read earlier histories of the Society, as well as classical historians such as Livy and Sallust featured in the curriculum of the Ratio. In echoing these authors, Jesuit house historians carried on a tradition of drawing on older and edifying models that stretched back to at least the Middle Ages. Yet the Cluj historia retains moments of vividness and specificity, as when we are told of a dramatic production of 1709 with "indutorum comicè adolescentium Reges et Angelos representantium, ac rhythmicos idiomate Hungarico versiculos declamatium" (youths dressed in a lighthearted fashion as kings and angels, declaiming rhythmic verses in Hungarian) ${ }^{68}$ We can sense the accomplishments in which the community took the greatest pride and the modes by which individual communities carried out their missions and engaged in selfrepresentation. At the same time, the accounts of events in historiae seem at times shaped, perhaps unconsciously, by the plots of Jesuit plays or devotional literature. All three categories of these generally anonymous documents are therefore particularly significant, and not merely for the way that less powerful members of

\footnotetext{
${ }^{65}$ For example, the elogium for Joannes Zaborsky, who died in Březnice u Př́brami (Bresnitz), Bohemia, in 1725. Markéta Holubová, "Kariérní dráhy členů jezuitského řádu působících v letech 1647-1773 v rezidenci na Svaté Hoře u Př́brami," Historická demografie 37, no. 2 (2013): 10120, here 109.

${ }^{66}$ Annuae residentiae Magno-Varadiensis S.J., 1722-1772, Ab 93, fol. 67 ${ }^{\mathrm{r}}$, ELTEK.

${ }^{67}$ Historia domestica residentiae S.J. Patakiensis S.J. 1663-1753, Ab 95, 87, ELTEK.

${ }^{68}$ Historia collegii Claudiopol, OSzK 2039/FMI/1608, 79.
} 


\section{Engaging Sources}

a community kept records. In the historia collegii of the Jesuit mission to Uzhgorod, Transcarpathia, is a marginal note: "Huc fui poeta" (From this point on, I was in the poetics class), with another note in a different hand: "Epp. Bacsin." 69 The Uniate bishop Andreas Bacsinsky (1732-1809) had apparently recalled his days in the school's poetics class, and another reader of this historia had recognized this. These and other clues are examples of how memoria reached back in time to reference these records, and how, once created, diaria, annuaria, and historiae each created space for subjective experience, which might be the raw material for a continually evolving community memoria forming a key part of the core of Jesuit identity up to - and beyond - the cataclysm of 1773.

These written contributions to the memoria of a Jesuit community existed within the context of less tangible forces that must be acknowledged even as we realize that their characteristics are harder to define. For many members of the pre-suppression Society, encounters with the supernatural both made up part of collective memoria and colored recollection of other events. And while oral history might keep alive recollection of these encounters, sometimes these events were enshrined in published (and illustrated) histories. ${ }^{70}$ Knowledge of previous encounters with the supernatural, especially those of an "infernal" nature, shaped expectations of later events. Jackdaws and blaspheming cows, for example, could not be understood as a manifestation of the divine.

On the other side of the coin, recollections of divine providence, especially when it brought deliverance, were explicitly shaped by narratives of earlier experiences. Here, an additional influence is often evident: the formulaic manner in which the Society's history had come to be recorded. At the micro level, performances at Jesuit schools were repeatedly described as having been received "non sine plausu" (not without applause). ${ }^{71}$ At the macro level, the "biography" of the Society is rendered in Imago primi saeculi (Image of the first century [of the Society]) in an anthropomorphic narrative arc as "nascens, crescens, patiens" (being born, growing, suffering) that calls to mind both the life of Christ and the collective experiences of Jesuit communities. ${ }^{72}$ Books like Imago contributed to Jesuit self-perception and thus indirectly to the expression of identity found in the documents reviewed here. The role of the Spiritual Exercises in shaping perceptions and language used in these records remains as of yet unexplored.

\footnotetext{
${ }^{69}$ Paul Shore, "The Life and Death of a Jesuit Mission: The Collegium in Uzhgorod, Transcarpathia (1650-1773)," Slavonic and East European Review 86, no. 4 (2008): 601-33, here 624n99.

${ }^{70}$ Rodrigo Gonzales (d.1580), for example, was tormented by two demons who broke his ribs and ultimately killed him. A widely circulated history depicted these demons pressing him under a heavy board. Matthias Tanner, Societas Jesu apostolorum imitatrix, sive Gesta praeclara et virtutes eorum [...] (Prague: Typis Universitatis Carlo-Ferdinandeæ, 1694), 171.

${ }^{71}$ Shore, "Jesuit Missions," 111.

${ }^{72}$ Imago primi saeculi (Antwerp: Ex officina Plantiniana Balthasaris Moreti, 1640).
} 
Diaria, historiae, and annuaria are receiving more attention from scholars and are increasingly accessible online, but they are scattered in many locations and vulnerable to loss, as when the historia and the diarium of the Požega (Croatia) collegium were damaged during the Second World War. ${ }^{73}$ Other diaria from Croatia may also have been lost. ${ }^{74}$ Still other historiae are reported in nineteenthcentury surveys of documents but have either so far eluded scholars' attention or are now missing. ${ }^{75}$ Moreover, because the term diarium was applied to a variety of approaches to recordkeeping, a focus on documents bearing this or that name may not produce a set of clear-cut patterns or conclusions unless other parameters are introduced. Yet however labeled, all these documents flesh out a more nuanced picture of the lived experience of Jesuits in a variety of settings and situations, adding to our understanding of the pre-suppression Society, and more broadly, of the Catholic world of the early modern period.

\footnotetext{
${ }^{73}$ Ivan Fuček, "Uvod u djelovanje Jurja Muliha: Z dvjesta sedamdeset petu godišnjicu njegova rođenja," Bogoslovska smotra 39, no. 4 (1969): 414-21, here 417.

${ }^{74}$ Ankica Landeka, "Knjižnica isusovačke misije iz Petrovaradina," Diacovensia 17, no. 1 (2009): 69-90, here 64.

${ }^{75}$ The current writer, for example, has been able to find no evidence of scholarship making use of the Historia collegii Klagenfurtensis. Stöger, Historiographi, 46.
} 